\title{
Effects of aerobic exercise training and irbesartan on blood pressure and heart rate variability in patients with chronic obstructive pulmonary disease
}

\author{
Karine Marquis $\mathrm{PhD}^{1}$, François Maltais $\mathrm{MD}^{1}$, Yves Lacasse $M D^{1}$, Yves Lacourcière $M D^{2}$, \\ Claudette Fortin t.EEP1, Paul Poirier MD PhD ${ }^{1}$
}

K Marquis, F Maltais, Y Lacasse, Y Lacourcière, C Fortin, P Poirier. Effects of aerobic exercise training and irbesartan on blood pressure and heart rate variability in patients with chronic obstructive pulmonary disease. Can Respir J 2008; 15(7):355-360.

BACKGROUND AND OBJECTIVES: The present pilot study was undertaken to evaluate the efficacy of an aerobic exercise training (AET) program alone or combined with an antihypertensive agent (irbesartan) to reduce blood pressure (BP) and enhance heart rate variability (HRV) in chronic obstructive pulmonary disease patients.

METHODS: Twenty-one patients were randomly assigned to a double-blind treatment with exercise and placebo $(n=11)$ or exercise and irbesartan $(\mathrm{n}=10)$. Subjects underwent $24 \mathrm{~h}$ BP monitoring and $24 \mathrm{~h}$ electrocardiographic recording before and after the 12 -week AET. HRV was investigated using three indexes from the power spectral analysis and three indexes calculated from the time domain. The AET program consisted of exercising on a calibrated ergocycle for 30 min three times per week. Five patients in the placebo group were excluded during follow-up because they were not compliant.

RESULTS: There was no change in $24 \mathrm{~h}$ systolic and diastolic BP before $(130 \pm 14 \mathrm{mmHg}$ and $70 \pm 3 \mathrm{mmHg}$, respectively) and after $(128 \pm 8 \mathrm{mmHg}$ and $70 \pm 8 \mathrm{mmHg}$, respectively) exercise training in the placebo group, whereas in the irbesartan group systolic and diastolic BP decreased from $135 \pm 9 \mathrm{mmHg}$ and $76 \pm 9 \mathrm{mmHg}$ to $126 \pm 12 \mathrm{mmHg}$ and $72 \pm 8 \mathrm{mmHg}$, respectively $(\mathrm{P}<0.02)$. There were no changes in HRV parameters in either group.

CONCLUSIONS: The present study suggests that a 12-week AET program is not associated with a significant reduction in BP or enhancement in HRV, whereas an AET program combined with irbesartan is associated with a reduction in $24 \mathrm{~h} \mathrm{BP}$.

\section{Effets d'un programme d'exercices aérobiques et de l'irbesartan sur la TA et la variabilité de la FC chez des patients souffrant de bronchopneumopathie obstructive chronique}

HISTORIQUE ET OBJECTIFS : La présente étude pilote a été entreprise pour évaluer l'efficacité d'un programme d'entraînement aérobique (EA), seul ou allié à un antihypertenseur (irbesartan), à réduire la tension artérielle (TA) et à améliorer la variabilité de la fréquence cardiaque (VFC) en présence de bronchopneumopathie obstructive chronique (BPOC).

MÉTHODES : Les auteurs ont assigné aléatoirement 21 patients à un traitement à double insu reposant sur l'exercice et un placebo $(\mathrm{n}=11)$ ou sur l'exercice et l'irbesartan $(\mathrm{n}=10)$. Les sujets ont été soumis à une surveillance de la tension artérielle et du rythme cardiaque des 24 heures avant, puis après les 12 semaines d'EA. La VFC a été vérifiée à l'aide de trois indices de l'analyse spectrale de puissance et de trois indices calculés à partir du domaine temporel. Le programme d'EA comportait une séance d'entraînement sur un ergocycle calibré pendant 30 minutes, trois fois par semaine. Cinq patients du groupe sous placebo ont été exclus durant le suivi en raison de leur piètre fidélité au protocole.

RÉSULTATS : On n'a observé aucun changement de la TA systolique et diastolique des 24 heures avant $(130 \pm 14 \mathrm{~mm} \mathrm{Hg}$ et $70 \pm 3 \mathrm{~mm} \mathrm{Hg}$, respectivement) et après $(128 \pm 8 \mathrm{~mm} \mathrm{Hg}$ et $70 \pm 8 \mathrm{~mm} \mathrm{Hg}$, respectivement) la séance d'exercice dans le groupe sous placebo, tandis que dans le groupe sous irbesartan, la TA systolique et diastolique est passée de $135 \pm$ $9 \mathrm{~mm} \mathrm{Hg}$ et de $76 \pm 9 \mathrm{~mm} \mathrm{Hg}$ à $126 \pm 12 \mathrm{~mm} \mathrm{Hg}$ et $72 \pm 8 \mathrm{~mm} \mathrm{Hg}$, respectivement $(\mathrm{p}<0,02)$. On n'a noté aucun changement quant aux paramètres de la VFC dans les deux groupes.

CONCLUSIONS : La présente étude laisse supposer qu'un programme d'EA de 12 semaines n'est associé à aucune réduction significative de la TA ni amélioration de la VFC, tandis qu'un programme d'EA allié à un traitement par irbesartan est associé à une réduction de la TA des 24 heures.

Key Words: Autonomic nervous system; Exercise training; Hypertension; Respiratory disease

Chronic obstructive pulmonary disease (COPD) is one of
the leading causes of morbidity and mortality worldwide
(1), and is increasing in prevalence (2). Furthermore, COPD is
frequently associated with comorbidities leading to cardiovas-
cular diseases (3). Of note, patients with COPD are at two- to
threefold increased risk of ischemic heart disease, stroke and
sudden cardiac death, independent of other risk factors $(4,5)$.

However, the mechanisms responsible for cardiovascular diseases in COPD patients remain largely speculative (6). High blood pressure (BP) at rest and during exercise is common in COPD patients (7-9). High BP is a well-known risk factor of cardiovascular diseases (10), and may be an important mechanism of cardiovascular morbidity and mortality in COPD patients. Because aerobic exercise training (AET) has been

${ }^{1}$ Centre de recherche de l'Hôpital Laval, Institut universitaire de cardiologie et de pneumologie de l'Université Laval; ${ }^{2}$ Unité de recherche en Hypertension, Centre hospitalier universitaire de Québec, Pavillon CHUL, Quebec City, Quebec

Correspondence: Dr Paul Poirier, Quebec Heart Institute, 2725 chemin Sainte-Foy, Sainte-Foy, Quebec City, Quebec G1V 4 G5.

Telephone 418-656-4767, fax 418-656-4581, e-mail paul.poirier@crhl.ulaval 
shown to reduce high BP in healthy subjects (11), this treatment modality might be effective at reducing systemic BP in COPD patients.

Previous studies (12-15) have shown that normoxemic and hypoxemic patients with COPD appear to have impaired cardiac autonomic modulation at rest, as reflected by reduced heart rate variability (HRV). Decreased HRV is associated with a higher incidence of cardiac death after acute myocardial infarction (16-19), and it is also associated with a higher incidence of cardiac events among subjects without previous coronary artery disease or chronic heart failure $(20,21)$. While AET has been associated with an increase in parasympathetic activity and the concomitant decrease of sympathetic activity in healthy subjects $(22,23)$, cardiac autonomic response to exercise training has not been well characterized in patients with COPD.

We hypothesized that AET could be an effective intervention to enhance HRV and lower BP in patients with COPD. Therefore, the present study was undertaken to evaluate the efficacy of an AET program alone or combined with an antihypertensive agent (irbesartan) on $24 \mathrm{~h}$ ambulatory BP and HRV in patients with COPD.

\section{METHODS}

Originally, 38 COPD patients from the cardiopulmonary rehabilitation program at Laval Hospital (Quebec City, Quebec) were recruited to participate in the present study. The patients included had a diagnosis of COPD based on previous or current smoking history, clinical evaluation and pulmonary function tests. Subjects with one of the following criteria were excluded from the study: recent heart failure or acute coronary syndrome (within three months), hepatic or renal dysfunction, significant thyroid disease, use of benzodiazepines or medications known to influence the autonomic nervous system (beta-adrenergic receptor blockers, alphaadrenergic receptor blockers, alpha-agonists), any connective tissue disease, osteoporosis and a history of malignancy. The patients were required to have an office resting BP greater than $140 / 90 \mathrm{mmHg}$ or an exercise BP greater than $220 / 100 \mathrm{mmHg}$ for inclusion in the present study. Current use of an antihypertensive agent was not an exclusion criterion, except for angiotensin receptor inhibitors and angiotensinconverting enzyme inhibitors. After a baseline evaluation, 21 patients were included in this protocol. The present study had a duration of three months. The participants were randomly assigned to a double-blind treatment with exercise and placebo $(n=11)$ or exercise and irbesartan $(n=10)$. The research protocol was approved by the institutional ethics committee, and signed informed consent was obtained from each subject.

\section{Choice of antihypertensive medication}

Several classes of antihypertensive medication are not well tolerated in individuals with COPD: beta-blockers may cause bronchospasm; angiotensin-converting enzyme inhibitors are often associated with cough; and calcium channel blockers may cause peripheral edema, a common problem in COPD. Angiotensin II receptor inhibitors are well tolerated and are usually free of adverse effects that may prevent their use in patients with COPD. A regimen of $150 \mathrm{mg}$ of irbesartan once per day was used.

\section{Assessments}

Before starting the present study, all patients underwent initial screening assessment that included a medical history and a physical examination.

\section{Anthropometric measurements}

Body weight and height were obtained from all participants. Body mass index was calculated by dividing weight (in kilograms) by the square of height (in metres).

\section{Pulmonary function tests and arterial blood gases}

Standard pulmonary function tests (including spirometry), lung volumes and diffusing capacity of the lung for carbon monoxide were obtained in all COPD patients according to recommended procedures (24). Results were compared with predicted normal values from the European Community for Coal and Steel/European Respiratory Society (25). Arterial $\mathrm{O}_{2}$ partial pressure and $\mathrm{CO}_{2}$ partial pressure were measured (AVL 995, AVL Scientific Corp, USA).

\section{Resting BP measurement}

Office BP measurements were obtained from each patient in the supine position after $15 \mathrm{~min}$ of rest. BP was taken in both arms and the highest measurement was used for analysis.

\section{$24 \mathrm{~h} \mathrm{BP}$ monitoring}

Ambulatory BP monitoring was conducted during a typical day. A $24 \mathrm{~h}$ ambulatory BP monitor measured BP at $20 \mathrm{~min}$ intervals between 06:00 and 11:00 (daytime), and at $30 \mathrm{~min}$ intervals between 23:00 and 06:00 (nighttime). Mean systolic $\mathrm{BP}(\mathrm{SBP})$ and diastolic BP (DBP) values were computed based on all valid readings. Accuracy of the ambulatory BP monitor was validated against a conventional mercury sphygmomanometer. To demonstrate adequate validity, the mean of three clinic and ambulatory BP measurements taken simultaneously were required to match within plus or minus $5 \mathrm{mmHg}$ (model 90207, SpaceLabs Inc, USA).

\section{Exercise test}

Subjects were seated on an electrically braked cycle ergometer (Corival 400, Lode, Netherlands) and connected to an expired gas analysis circuit through a mouthpiece. The gas analysis circuit consisted of a pneumotachograph, $\mathrm{O}_{2}$ and $\mathrm{CO}_{2}$ analyzers, and a mixing chamber (Qplex, Quinton Instruments Co, USA). After a $5 \mathrm{~min}$ period of rest, a progressive stepwise exercise test was performed until exhaustion. Five-breath averages of ventilation, oxygen uptake $\left(\mathrm{VO}_{2}\right)$ and $\mathrm{CO}_{2}$ production were obtained. These parameters were measured at rest and during exercise testing. Each exercise stage lasted $1 \mathrm{~min}$ and increments of $10 \mathrm{~W}$ were used. Heart rate and BP were measured at $1 \mathrm{~min}$ and $2 \mathrm{~min}$ intervals, respectively, during the exercise test. BP measurements were taken with an automatic BP monitor (model 410, Quinton Instruments Co, USA).

\section{Exercise training}

The AET program for the COPD patients consisted of exercising on a calibrated ergocycle for 30 min three times per week for 12 weeks. The work rate was set at $80 \%$ of the maximal power output evaluated during the $\dot{\mathrm{VO}}_{2}$ max evaluation. During the training sessions, patients were closely supervised by a physiotherapist and an exercise physiologist to help them 
TABLE 1

Baseline characteristics of subjects

\begin{tabular}{|c|c|c|}
\hline Characteristic & $\begin{array}{c}\text { Irbesartan } \\
n=10\end{array}$ & $\begin{array}{c}\text { Placebo } \\
n=6\end{array}$ \\
\hline Age, years & $67 \pm 7$ & $72 \pm 5$ \\
\hline Sex (female/male) & $3 / 7$ & $5 / 1$ \\
\hline Body mass index, $\mathrm{kg} / \mathrm{m}^{2}$ & $28.9 \pm 6.3$ & $23.6 \pm 4.1$ \\
\hline FVC, L & $2.19 \pm 0.68$ & $1.76 \pm 0.56$ \\
\hline FVC, \% predicted & $63 \pm 16$ & $63 \pm 15$ \\
\hline $\mathrm{FEV}_{1}, \mathrm{~L}$ & $1.21 \pm 0.45$ & $0.72 \pm 0.21^{*}$ \\
\hline $\mathrm{FEV}_{1}, \%$ predicted & $50 \pm 19$ & $39 \pm 9$ \\
\hline $\mathrm{FEV}_{1} / \mathrm{FVC}$ & $56 \pm 14$ & $42 \pm 7^{*}$ \\
\hline Total lung capacity, $\%$ predicted & $117 \pm 20$ & $129 \pm 15$ \\
\hline Residual volume, \% predicted & $179 \pm 48$ & $244 \pm 71$ \\
\hline Residual volume/total lung capacity & $53 \pm 11$ & $61 \pm 11$ \\
\hline $\mathrm{DL}_{\mathrm{CO}}, \%$ predicted & $80 \pm 19$ & $63 \pm 18$ \\
\hline $\mathrm{PaO}_{2}, \mathrm{mmHg}$ & $87 \pm 13$ & $88 \pm 12$ \\
\hline $\mathrm{PaCO}_{2}, \mathrm{mmHg}$ & $41 \pm 6$ & $43 \pm 5$ \\
\hline
\end{tabular}

Values are presented as mean $\pm S D$, unless otherwise indicated. ${ }^{*} P<0.05$ versus irbesartan. $D L_{c o}$ Diffusing capacity of the lung for carbon monoxide; FEV ${ }_{1}$ Forced expiratory volume in $1 \mathrm{~s}$; FVC Forced vital capacity; $\mathrm{PaCO}_{2}$ Partial pressure of $\mathrm{CO}_{2} ; \mathrm{PaO}_{2}$ Partial pressure of $\mathrm{O}_{2}$

reach their target training workload intensity. The session also included upper extremity exercises, self-pace walking, stretching and relaxing. Detailed information on exercise prescription and supervision modalities used in this program have been previously published (26).

\section{HRV}

The presence of subclinical cardiac autonomic dysfunction was evaluated with HRV indexes. HRV was derived from a $24 \mathrm{~h}$ electrocardiographic (ECG) recording (Holter series 8500, Marquette Electronics, USA) assessed while subjects performed their usual daily activities. HRV, using frequency and time domains, was assessed and several indexes were determined. The powers of very low frequency (LF) $(0.0033 \mathrm{~Hz}$ to $0.04 \mathrm{~Hz})$ and LF $(0.04 \mathrm{~Hz}$ to $0.15 \mathrm{~Hz})$ are considered to be an index of both sympathetic and parasympathetic activity, whereas the power of high frequency (HF) $(0.15 \mathrm{~Hz}$ to $0.4 \mathrm{~Hz})$ is considered to be an index of solely parasympathetic activity. The LF/HF ratio was calculated, which reflects sympathovagal balance. Using the time domain, the SD of the normal-to-normal (NN) intervals, which is the square root of variance and which reflects all the cyclic components responsible for variability in the period of recording, was calculated; it is an estimate of overall HRV. NN intervals included all intervals between adjacent QRS complexes resulting from sinus node depolarization in the entire $24 \mathrm{~h}$ ECG recording. The square root of the mean squared differences of successive NN intervals, which is an estimate of short-term components of HRV, was also calculated. Finally, the SD of the average NN intervals calculated over 5 min periods, which is an estimate of long-term components of HRV, was determined. The complete signal was carefully edited using visual checks and manual correction of individual NN intervals and QRS complex classifications.

\section{Statistical analysis}

Descriptive statistics were used to compare characteristics of the two groups. Data were reported as mean $\pm \mathrm{SD}$ unless otherwise
TABLE 2

Blood pressure at baseline and after a 12-week aerobic exercise training program

\begin{tabular}{|c|c|c|c|c|}
\hline & $\begin{array}{l}\text { Irbesartan } \\
\text { plus } \\
\text { exercise } \\
\text { (baseline) }\end{array}$ & $\begin{array}{l}\text { Placebo } \\
\text { plus } \\
\text { exercise } \\
\text { (baseline) }\end{array}$ & $\begin{array}{c}\text { Irbesartan } \\
\text { plus } \\
\text { exercise } \\
\text { (post-training) }\end{array}$ & $\begin{array}{c}\text { Placebo } \\
\text { plus } \\
\text { exercise } \\
\text { (post-training) }\end{array}$ \\
\hline Resting SBP, mmHg & $151 \pm 19$ & $140 \pm 15$ & $131 \pm 18^{*}$ & $136 \pm 15$ \\
\hline Resting DBP, mmHg & $78 \pm 8$ & $72 \pm 8$ & $71 \pm 10^{*}$ & $68 \pm 10$ \\
\hline $24 \mathrm{~h}$ SBP, mmHg & $135 \pm 9$ & $130 \pm 14$ & $126 \pm 12^{\dagger}$ & $128 \pm 8$ \\
\hline $24 \mathrm{~h} \mathrm{DBP}, \mathrm{mmHg}$ & $76 \pm 9$ & $70 \pm 3$ & $72 \pm 8^{*}$ & $70 \pm 8$ \\
\hline Daytime SBP, mmHg & $139 \pm 11$ & $130 \pm 14$ & $129 \pm 15^{\dagger}$ & $131 \pm 8$ \\
\hline Daytime DBP, mmHg & $80 \pm 11$ & $71 \pm 2$ & $74 \pm 10^{*}$ & $72 \pm 7$ \\
\hline Nighttime SBP, mmHg & $125 \pm 8$ & $128 \pm 16$ & $121 \pm 10$ & $121 \pm 9$ \\
\hline Nighttime DBP, mmHg & $68 \pm 6$ & $66 \pm 6$ & $67 \pm 7$ & $65 \pm 8$ \\
\hline $\begin{array}{l}\text { Maximal exercise SBP, } \\
\quad \mathrm{mmHg}\end{array}$ & $237 \pm 27$ & $211 \pm 34$ & $220 \pm 27^{*}$ & $195 \pm 36$ \\
\hline $\begin{array}{l}\text { Maximal exercise DBP, } \\
\mathrm{mmHg}\end{array}$ & $98 \pm 17$ & $102 \pm 28$ & $86 \pm 14^{*}$ & $82 \pm 31$ \\
\hline Work rate, $\mathrm{W}$ & $95 \pm 27$ & $48 \pm 20$ & $107 \pm 29^{*}$ & $54 \pm 19$ \\
\hline Peak $\dot{\mathrm{V}} \mathrm{O}_{2}, \mathrm{~mL} / \mathrm{min} / \mathrm{kg}$ & $15 \pm 3$ & $11 \pm 4$ & $16 \pm 3$ & $11 \pm 3$ \\
\hline
\end{tabular}

Values are presented as mean $\pm S D$. ${ }^{*} P<0.05$ before and after irbesartan; ${ }^{t} P<0.01$ before and after irbesartan. DBP Diastolic blood pressure; SBP Systolic blood pressure; $\dot{\mathrm{V}} \mathrm{O}_{2}$ Oxygen uptake

specified. Statistical analysis was performed using the unpaired $t$ test to compare the irbesartan and placebo groups at baseline and after the training program, and a paired $t$ test was used to compare the effect of physical training and treatment in both groups. A Mann-Whitney rank sum test was used when the equal variance test failed. A $\chi^{2}$ test and a Fisher's exact test were performed to compare proportions when appropriate. A value of $\mathrm{P}<0.05$ was considered statistically significant.

Study sample

\section{RESULTS}

At the beginning of the recruitment, 38 COPD patients performed baseline evaluation. However, some of them met exclusion criteria: 10 patients took antihypertensive medication such as angiotensin receptor inhibitors and angiotensinconverting enzyme inhibitors, five patients had a resting $\mathrm{BP}$ below $140 / 90 \mathrm{mmHg}$, and two patients had decided not to participate in the exercise program. Thus, only 21 patients were randomly assigned in the present study (10 in the irbesartan group and 11 in the placebo group). Furthermore, five patients in the placebo group were excluded during the follow-up. The reasons for premature withdrawal during this double-blind treatment period included the presence of side effects and noncompliance to placebo or exercise training. Thus, for the analysis, 10 patients were in the irbesartan group and six patients were in the placebo group.

\section{Baseline evaluation}

The characteristics of patients in the irbesartan group and in the placebo group who completed the study are shown in Table 1. Age and body mass index were comparable between both groups. Airflow obstruction was more severe in the placebo group than in the irbesartan group (forced expiratory volume in $1 \mathrm{~s} /$ forced vital capacity: $42 \pm 7 \%$ predicted versus $56 \pm 14 \%$ predicted, respectively; $\mathrm{P}<0.05$ ). Arterial blood gases were similar between the two groups. Table 2 shows that resting BP, 
TABLE 3

Heart rate variability indexes at baseline and after a 12-week aerobic exercise training program

\begin{tabular}{lcccc}
\hline & $\begin{array}{c}\text { Irbesartan } \\
\text { plus } \\
\text { exercise } \\
\text { (baseline) }\end{array}$ & $\begin{array}{c}\text { Placebo } \\
\text { plus } \\
\text { exercise } \\
\text { (baseline) }\end{array}$ & $\begin{array}{c}\text { Irbesartan } \\
\text { plus } \\
\text { exercise } \\
\text { (post-training) }\end{array}$ & $\begin{array}{c}\text { Placebo } \\
\text { plus } \\
\text { exercise } \\
\text { (post-training) }\end{array}$ \\
\hline SDNN, ms & $134 \pm 30$ & $121 \pm 27$ & $144 \pm 36$ & $113 \pm 38$ \\
p-NN50, \% & $9 \pm 9$ & $10 \pm 9$ & $9 \pm 8$ & $10 \pm 8$ \\
r-MSSD, ms & $30 \pm 12$ & $31 \pm 11$ & $29 \pm 11$ & $30 \pm 10$ \\
VLF, ms & $3.27 \pm 0.20$ & $3.06 \pm 0.25$ & $3.27 \pm 0.21$ & $3.09 \pm 0.51$ \\
LF, ms & $2.92 \pm 0.32$ & $2.76 \pm 0.44$ & $2.91 \pm 0.32$ & $2.77 \pm 0.42$ \\
HF, ms & $2.41 \pm 0.34$ & $2.42 \pm 0.37$ & $2.40 \pm 0.41$ & $2.37 \pm 0.45$ \\
LF/HF ratio & $2.96 \pm 1.25$ & $2.12 \pm 1.00$ & $3.06 \pm 1.32$ & $2.38 \pm 0.95$ \\
\hline
\end{tabular}

Values are presented as mean $\pm S D$. HF High frequency; LF Low frequency; p-NN50 Percentage of adjacent normal-to-normal (NN) intervals differing by more than $50 \mathrm{~ms}$; $r$-MSSD Square root of the mean squared differences of successive NN intervals; SDNN Standard deviation of all NN intervals; VLF Very low frequency

$24 \mathrm{~h}$ BP, daytime BP, nighttime BP and maximal exercise BP were comparable between the irbesartan group and the placebo group at baseline. The HRV indexes in the time and frequency domains were also similar at baseline between both groups (Table 3).

\section{Effects of exercise training on BP}

In the study, 16 patients completed the 12-week training program and participated in an average of $30 \pm 2$ sessions (range, 26 to 33 sessions) representing a compliance rate of $91 \pm 6 \%$. Resting BP, $24 \mathrm{~h}$ BP, daytime BP and maximal exercise BP decreased significantly in the irbesartan group, whereas these parameters did not change significantly in the placebo group (Table 2). Nighttime SBP and DBP did not change in both groups.

\section{Effects of exercise training on HRV}

HRV indexes did not change following the 12-week AET program in either group (Table 3 ).

\section{DISCUSSION}

To our knowledge, this is the first report evaluating the effects of an AET program alone or combined with an antihypertensive agent on resting BP, $24 \mathrm{~h}$ ambulatory BP, maximal exercise $\mathrm{BP}$ and HRV in patients with COPD. The present study suggests that a 12-week AET program was not associated with a statistically significant reduction in resting BP, $24 \mathrm{~h}$ ambulatory $\mathrm{BP}$, daytime $\mathrm{BP}$, nighttime $\mathrm{BP}$, maximal exercise $\mathrm{BP}$ or an enhancement in HRV in COPD patients. However, we observed that AET combined with irbesartan was associated with a reduction in resting BP, $24 \mathrm{~h} \mathrm{BP}$, daytime BP and maximal exercise BP. However, AET combined with irbesartan failed to reduce nighttime BP or to enhance HRV indexes in patients with COPD.

Exercise programs that primarily involve endurance activity constitute a cornerstone therapy for the primary prevention, treatment and control of systemic hypertension. The Seventh Report of the Joint National Committee on Prevention, Detection, Evaluation, and Treatment of High Blood Pressure (10), the Canadian recommendations for the management of hypertension (27) and the European Society of Hypertension-European Society of Cardiology guidelines (28) recommend regular physical exercise for the prevention of high BP and the management of patients with hypertension. Although the optimal training frequency, intensity, time and type of exercise needs to be better defined to optimize the BP lowering influence of exercise (11), particularly in specific populations such as COPD patients, we applied the recommended exercise prescription for patients with high BP in our study. However, the positive effect of exercise on hypertension in older individuals is not clear $(29,30)$. Indeed, randomized controlled trials assessing the effects of chronic aerobic exercise on resting BP in normotensive and hypertensive adults (older than 50 years of age) have led to conflicting results $(29,30)$. In the study by Hagberg et al $(30)$, it was reported that moderate intensity exercise training $(70 \%$ to $85 \% \dot{\mathrm{VO}}_{2} \max$ ) in hypertensive older individuals (60 to 69 years of age) failed to reduce resting SBP significantly. In contrast, Cononie et al (29) showed that endurance exercise training produces a significant reduction in resting SBP in individuals 70 to 79 years of age. Results regarding the impact of AET on ambulatory BP in older adults are also conflicting (31-33). Seals and Reiling (33) showed that $24 \mathrm{~h}$ BP was unchanged in older hypertensive individuals after six months of regular AET. In contrast, Jessup et al (32) reported that a 16 -week endurance exercise training program decreases mean $24 \mathrm{~h}$ ambulatory SBP and DBP significantly in normotensive older adults. In this study, the participants completed a 16-week endurance exercise training program, and the training consisted of exercising for $1 \mathrm{~h}$ three times a week on treadmills and stair-climbers. In our study, the patients performed a 12 -week AET program, 30 min three times a week on an ergocycle. In the study by Jessup et al (32), peak $\dot{\mathrm{VO}}$, increased by $14 \%(\mathrm{P}=0.001)$, whereas it did not change significantly in our patients; perhaps our exercise stimulus was too light to increase exercise capacity and therefore decrease SBP.

In the present study, mean resting and $24 \mathrm{~h}$ ambulatory SBP were $140 \pm 15 \mathrm{mmHg}$ and $130 \pm 14 \mathrm{mmHg}$, respectively, at baseline in the placebo group. The patients in our study were practically normotensive at baseline. Exercise training is recognized as being more effective at reducing BP in young hypertensive patients compared with young normotensive patients (11). Therefore, it may not be surprising that the decrease in resting and ambulatory BP were not significant after the training program, especially in light of no significant increase in $\mathrm{VO}_{2}$ maximum. In accordance with the literature, maximal exercise BP was unchanged after AET in our study (34).

AET is recognized as an efficient modality to enhance HRV in healthy subjects. More specifically, Schuit et al (35) demonstrated that regular physical activity increases HRV in older healthy subjects and effects of training were more pronounced in the most sedentary subjects at baseline. COPD patients may be considered inactive compared with healthy subjects matched for age. Nevertheless, we found that a 12-week aerobic program was not associated with enhanced HRV in COPD patients.

Irbesartan is an angiotensin II receptor antagonist recognized to reduce resting and ambulatory BP (36). Once-daily administration of irbesartan to healthy subjects and individuals with mild-to-moderate systemic hypertension lowered BP $24 \mathrm{~h}$ after intake in a dose-dependent manner (36). In our study, 
exercise training combined with irbesartan reduced resting BP, $24 \mathrm{~h}$ ambulatory BP, daytime BP and maximal exercise BP in COPD patients.

Exercise training combined with irbesartan was not efficient at enhancing HRV in patients with COPD. Losartan, another angiotensin II receptor antagonist, has been reported to enhance HRV in patients with uncomplicated essential hypertension (37). However, clinical trials regarding the impacts of antihypertensive treatment on HRV have reported mixed results $(37,38)$. These studies varied considerably in study design, including age and types of participants (healthy subjects versus hypertensive patients), BP regimen, duration and route of antihypertensive therapy, and methodology of assessment of HRV, making comparison in terms of the influence of treatment on HRV limited. COPD patients are a specific population and the lack of effect of irbesartan on HRV needs further study.

The major limitation of the current study is the number of participants at the end of the study. Only six patients in the placebo group and 10 patients in the irbesartan group completed the training program. One of these patients refused to complete the final evaluation, including the $24 \mathrm{~h}$ ambulatory
BP monitoring and the $24 \mathrm{~h}$ ECG recording. Thus, data reported here should be considered as pilot findings.

\section{CONCLUSIONS}

The present results suggest that AET is not associated with a reduction in $\mathrm{BP}$ or enhanced HRV in COPD patients. The addition of AET with irbesartan may be effective at decreasing resting $\mathrm{BP}, 24 \mathrm{~h}$ ambulatory $\mathrm{BP}$, daytime $\mathrm{BP}$ and maximal exercise BP in this specific population.

ACKNOWLEDGEMENTS: The authors thank Marthe Bélanger, Marie-Josée Breton and Brigitte Jean for their technical assistance.

FUNDING: This study was supported by a grant from BristolMyers Squibb.

DISCLOSURE OF POTENTIAL CONFICTS OF INTEREST:

P Poirier is a clinician-scientist of the Fonds de recherche en Santé du Québec. F Maltais is a research scholar of the Fonds de Recherche en Santé du Québec. K Marquis is a recipient of a $\mathrm{PhD}$ training award of the Canadian Institutes of Health Research.

\section{REFERENCES}

1. Pauwels RA, Rabe KF. Burden and clinical features of chronic obstructive pulmonary disease (COPD). Lancet 2004;364:613-20.

2. Murray CJ, Lopez AD. Alternative projections of mortality and disability by cause 1990-2020: Global Burden of Disease Study. Lancet 1997;349:1498-504.

3. Agusti AG, Noguera A, Sauleda J, Sala E, Pons J, Busquets X. Systemic effects of chronic obstructive pulmonary disease. Eur Respir J 2003;21:347-60

4. Friedman GD, Klatsky AL, Siegelaub AB. Lung function and risk of myocardial infarction and sudden cardiac death. N Engl J Med 1976;294:1071-5.

5. Engström G, Lind P, Hedblad B, et al. Lung function and cardiovascular risk: Relationship with inflammation-sensitive plasma proteins. Circulation 2002;106:2555-60.

6. Sin DD, Man SF. Why are patients with chronic obstructive pulmonary disease at increased risk of cardiovascular diseases? The potential role of systemic inflammation in chronic obstructive pulmonary disease. Circulation 2003;107:1514-9.

7. Maltais F, Whittom F, LeBlanc P, Marquis K, Belleau R, Jobin J. Blood pressure and double product increase during exercise in patients with COPD. Am J Respir Crit Care Med 1998;157:A451.

8. Antonelli Incalzi R, Fuso L, De Rosa M, et al. Co-morbidity contributes to predict mortality of patients with chronic obstructive pulmonary disease. Eur Respir J 1997;10:2794-800.

9. Fabbri LM, Rabe KF. From COPD to chronic systemic inflammatory syndrome? Lancet 2007;370:797-9.

10. Chobanian AV, Bakris GL, Black HR, et al. Seventh report of the Joint National Committee on Prevention, Detection, Evaluation, and Treatment of High Blood Pressure. Hypertension 2003;42:1206-52.

11. Pescatello LS, Franklin BA, Fagard R, Farquhar WB, Kelley GA, Ray CA. American College of Sports Medicine position stand. Exercise and hypertension. Med Sci Sports Exerc 2004;36:533-53.

12. Stewart AG, Waterhouse JC, Howard P. Cardiovascular autonomic nerve function in patients with hypoxaemic chronic obstructive pulmonary disease. Eur Respir J 1991;4:1207-14.

13. Volterrani M, Scalvini S, Mazzuero G, et al. Decreased heart rate variability in patients with chronic obstructive pulmonary disease. Chest 1994;106:1432-7.

14. Stein PK, Nelson P, Rottman JN, et al. Heart rate variability reflects severity of COPD in PiZ alpha1-antitrypsin deficiency. Chest 1998;113:327-33.

15. Scalvini S, Porta R, Zanelli E, et al. Effects of oxygen on autonomic nervous system dysfunction in patients with chronic obstructive pulmonary disease. Eur Respir J 1999;13:119-24.
16. Wolf MM, Varigos GA, Hunt D, Sloman JG. Sinus arrhythmia in acute myocardial infarction. Med J Aust 1978;2:52-3.

17. Kleiger RE, Miller JP, Bigger JT Jr, Moss AJ. Decreased heart rate variability and its association with increased mortality after acute myocardial infarction. Am J Cardiol 1987;59:256-62.

18. Bigger JT Jr, Fleiss JL, Steinman RC, Rolnitzky LM, Kleiger RE, Rottman JN. Frequency domain measures of heart period variability and mortality after myocardial infarction. Circulation 1992;85:164-71.

19. Farrell TG, Bashir Y, Cripps T, et al. Risk stratification for arrhythmic events in postinfarction patients based on heart rate variability, ambulatory electrocardiographic variables and the signal-averaged electrocardiogram. J Am Coll Cardiol 1991;18:687-97.

20. Tsuji H, Venditti FJ Jr, Manders ES, et al. Reduced heart rate variability and mortality risk in an elderly cohort. The Framingham Heart Study. Circulation 1994;90:878-83.

21. Tsuji H, Larson MG, Venditti FJ Jr, et al. Impact of reduced heart rate variability on risk for cardiac events. The Framingham Heart Study. Circulation 1996;94:2850-5.

22. Melanson EL, Freedson PS. The effect of endurance training on resting heart rate variability in sedentary adult males. Eur J Appl Physiol 2001;85:442-9.

23. Tuomainen P, Peuhkurinen K, Kettunen R, Rauramaa R. Regular physical exercise, heart rate variability and turbulence in a 6-year randomized controlled trial in middle-aged men: The DNASCO study. Life Sci 2005;77:2723-34.

24. Miller MR, Hankinson J, Brusasco V, et al. [Standardisation of spirometry.] Rev Mal Respir 2007;24:2S27-49.

25. Quanjer PH, Tammeling GJ, Cotes JE, Pedersen OF, Peslin R, Yernault JC. Lung volumes and forced ventilatory flows. Work Group on Standardization of Respiratory Function Tests. European Community for Coal and Steel. Official position of the European Respiratory Society. Rev Mal Respir 1994;11(Suppl 3):S5-40.

26. Maltais F, LeBlanc P, Simard C, et al. Skeletal muscle adaptation to endurance training in patients with chronic obstructive pulmonary disease. Am J Respir Crit Care Med 1996;154:442-7.

27. Touyz RM, Campbell N, Logan A, Gledhill N, Petrella R, Padwal R. The 2004 Canadian recommendations for the management of hypertension: Part III - Lifestyle modifications to prevent and control hypertension. Can J Cardiol 2004;20:55-9.

28. 2003 European Society of Hypertension-European Society of Cardiology guidelines for the management of arterial hypertension. J Hypertens 2003;21:1011-53. (Errata in 2003;21:2203-4 and 2004;22:435). 
29. Cononie CC, Graves JE, Pollock ML, Phillips MI, Sumners C, Hagberg JM. Effect of exercise training on blood pressure in 70 - to 79-yr-old men and women. Med Sci Sports Exerc 1991;23:505-11.

30. Hagberg JM, Montain SJ, Martin WH 3rd, Ehsani AA. Effect of exercise training in 60- to 69-year-old persons with essential hypertension. Am J Cardiol 1989;64:348-53.

31. Pescatello LS, Kulikowich JM. The aftereffects of dynamic exercise on ambulatory blood pressure. Med Sci Sports Exerc 2001;33:1855-61.

32. Jessup JV, Lowenthal DT, Pollock ML, Turner T. The effects of endurance exercise training on ambulatory blood pressure in normotensive older adults. Geriatr Nephrol Urol 1998;8:103-9.

33. Seals DR, Reiling MJ. Effect of regular exercise on 24-hour arterial pressure in older hypertensive humans. Hypertension 1991;18:583-92.

34. Van Hoof R, Hespel P, Fagard R, Lijnen P, Staessen J, Amery A. Effect of endurance training on blood pressure at rest, during exercise and during 24 hours in sedentary men. Am J Cardiol 1989;63:945-9.

35. Schuit AJ, van Amelsvoort LG, Verheij TC, et al. Exercise training and heart rate variability in older people. Med Sci Sports Exerc 1999;31:816-21.

36. Fogari R, Ambrosoli S, Corradi L, et al. 24-hour blood pressure control by once-daily administration of irbesartan assessed by ambulatory blood pressure monitoring. Irbesartan Multicenter Investigators' Group. J Hypertens 1997;15:1511-8.

37. Chern CM, Hsu HY, Hu HH, Chen YY, Hsu LC, Chao AC. Effects of atenolol and losartan on baroreflex sensitivity and heart rate variability in uncomplicated essential hypertension. J Cardiovasc Pharmacol 2006;47:169-74.

38. Ylitalo A, Airaksinen KE, Sellin L, Huikuri HV. Effects of combination antihypertensive therapy on baroreflex sensitivity and heart rate variability in systemic hypertension. Am J Cardiol 1999;83:885-9. 


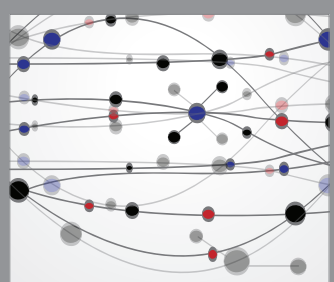

The Scientific World Journal
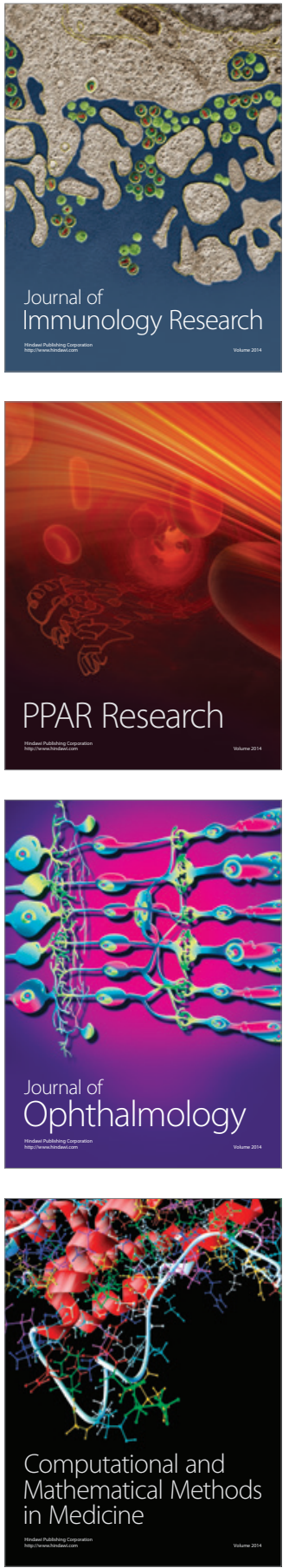

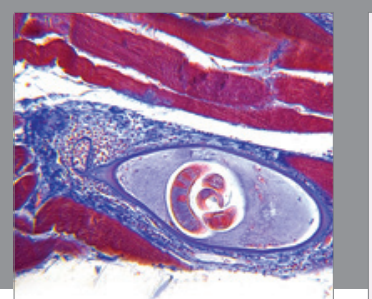

Gastroenterology Research and Practice

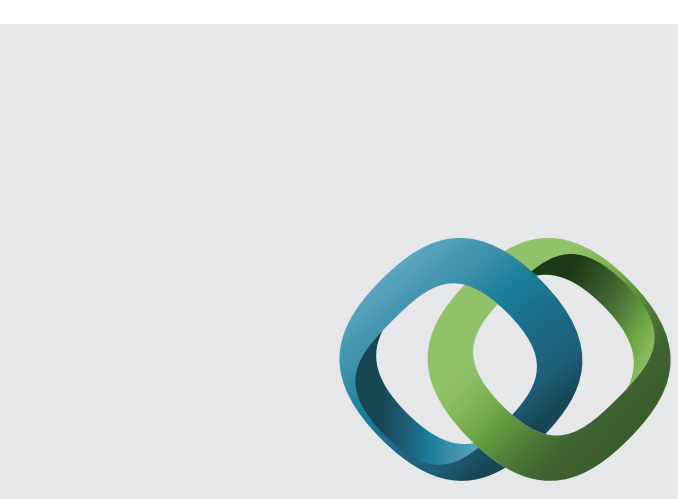

\section{Hindawi}

Submit your manuscripts at

http://www.hindawi.com
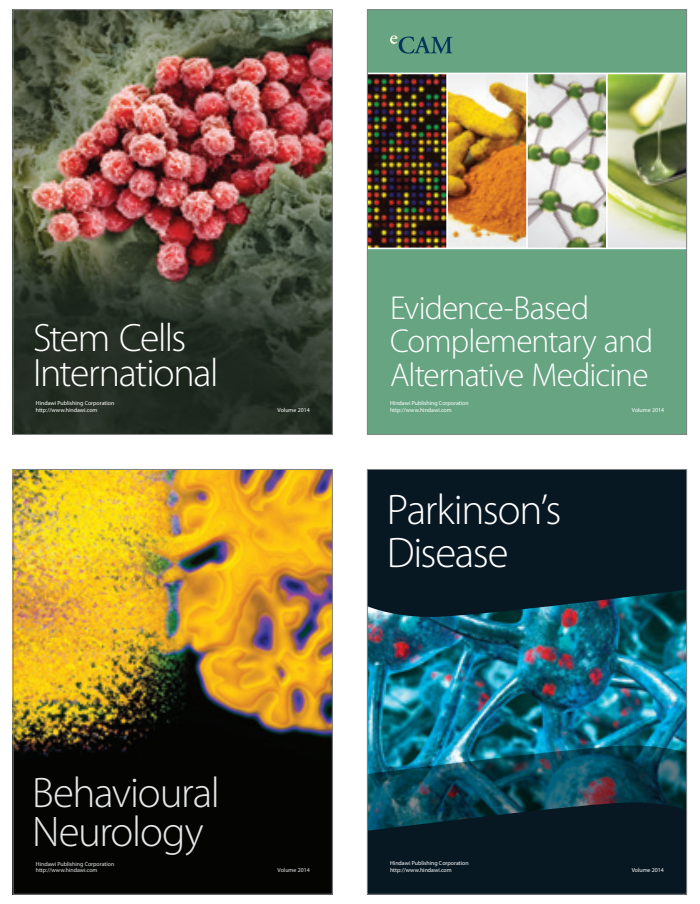
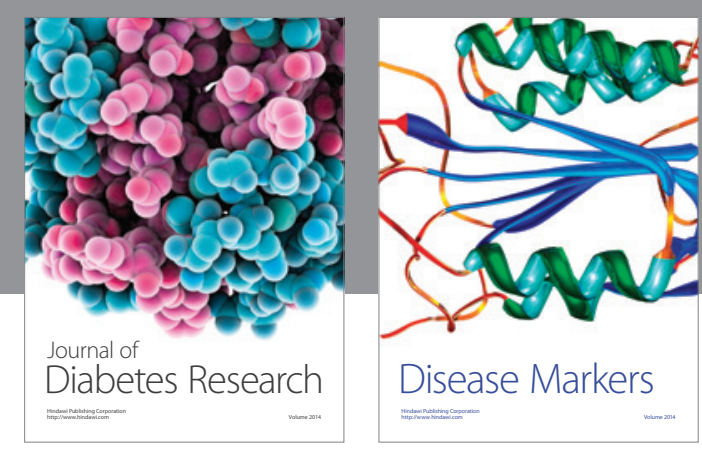

Disease Markers
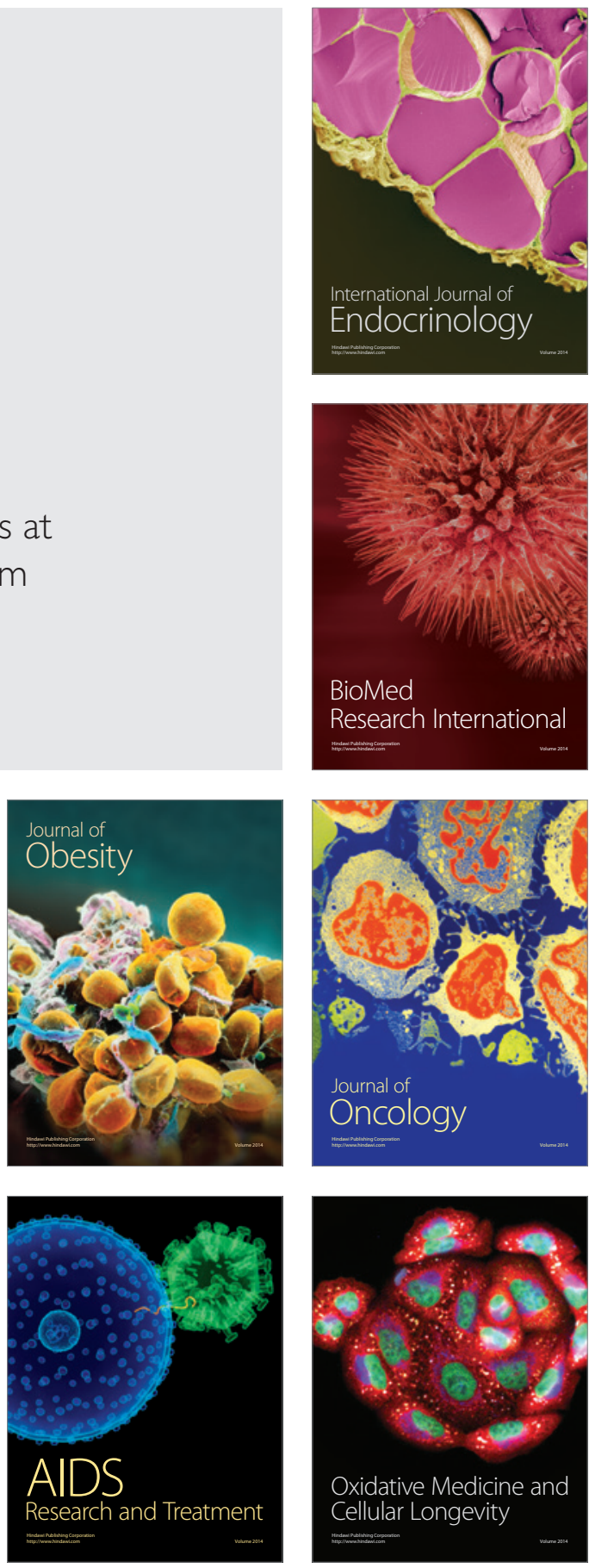